\title{
EDITORIAL
}

\section{Humanitas et SCIEnTiae}

$\mathfrak{E}$ n el mural que decora el ábside de la Capilla Sixtina se aprecian escenas del Juicio Final, un alma de figura antropomorfa esta rodeada de una serpiente que le muerde el muslo mientras dos demonios lo arrastran hacia el infierno. El rostro de desconsuelo de aquella alma condensa el desasosiego que experimentan millones de humanos ante situaciones trágicas. Metros más allá, ángeles y demonios, vivos y muertos, santos y laicos libran la batalla definitiva que tiene como centro a un Jesucristo triunfante. Este fresco de Michelangelo Buonarroti esta cargado de imágenes que representan la condición humana, sus temores, creencias y anhelos. Allí se retrata lo efímero de la vida, la eternidad de la muerte, las debilidades y grandezas humanas. El artista posee, además de una exquisita técnica pictórica, una extraordinaria capacidad de observación del devenir humano.

Pero no solo se trata de observación. Interpretar la condición humana a través del arte significa entre otras cosas, identificarse con el otro, reconocer su presencia y su diversidad. Esto es lo que caracteriza a las obras de arte que trascienden. Lo mismo podría decirse de aquellas obras que interpretan y reproducen la armonía de la naturaleza.

Entonces, se asume que el artista se nutre de las expresiones múltiples de la condición humana. Del mismo modo, el ejercicio de la medicina expone a los profesionales y a los estudiantes de pre y posgrado a tal variedad de experiencias. Así, las humanidades y las ciencias médicas son disciplinas que vienen a ser dos caras de la misma moneda ya que comparten el mismo objeto de estudio, el ser humano.

Se puede decir que el ejercicio liberal de las artes y de la medicina tiene como cauce común el bienestar de las personas dentro de una comunidad que debiera ser justa, tolerante e inclusiva. La universidad, en tanto espacio sin límites para el desarrollo del saber, debiera ser el punto de encuentro natural de ambas disciplinas.

Sin embargo, en los últimos años, debido a diversas necesidades tanto académicas, administrativas como a demandas de la sociedad, léase mercado laboral, se han producido cambios en la estructura curricular en desmedro de la enseñanza de las humanidades que privilegian, tanto en las necesidades percibidas por los estudiantes como en la priorización de la carga docente, a disciplinas consideradas prioritarias para la futura práctica profesional.

En principionoestá mal queel grueso de la carga académica sea ocupado por las ciencias básicas, las ciencias clínicas y las horas de práctica clínica preprofesional. Es imprescindible que esto suceda. Sin embargo, aparece cierta preocupación cuando, amparados por el dictum cartesiano de dividir las materias en 
tantas partes como sea posible, en beneficio de una mayor comprensión, se establezcan muros entre las disciplinas científicas y las humanistas que funcionan como divisoria de aguas y haciéndolas ver como ajenas, excluyentes o incluso antagónicas.

Cuando un médico desarrolla su labor profesional debe tener presente que frente a sí no solo tiene a un cuerpo con toda su maquinaria metabólica sino a una persona que tiene una identidad, creencias y una cultura, además de una historia determinada por el entorno en el que ha crecido y desarrollado. En síntesis, un todo que es más que la suma de las partes; pero, se aprecia en el ejercicio actual de la medicina una tendencia a la cosificación y tecnificación, a un apego cuasi dogmático a los procedimientos, métricas y guías clínicas antes que poner tales marcos normativos o escalas de puntaje en el contexto particular de cada caso. Parece ser que se inclina la balanza a atender enfermedades y no enfermos.

Para recolocar el foco de atención en el todo, en la persona en sí, se requiere algo más que el apego escrupuloso a las técnicas científicas. Se necesita desarrollar el juicio crítico, la curiosidad por saber más, así como una comprensión de las necesidades del otro. Se hace imperativo el fomentar la creación de estudiantes con una densidad cultural que los acerque a la humanitas planteada originalmente por Cicerón y retomada por Petrarca, es decir el sentido de lo humano, cargado de empatía, tolerancia y respeto. En el caso de la medicina, lo humano es interesarse por la enfermedad que padece la persona, con sus matices particulares antes que a la aséptica aproximación de que toda enfermedad se aborda de la misma manera. Las formas de presentación de la enfermedad, así como la respuesta al tratamiento, están condicionadas por el comportamiento y los denominados determinantes sociales. Entender este lado humano nos dará mejores herramientas de trabajo.

Las humanidades aproximan la medicina a los abismos y alturas de la condición humana. La lectura de un libro, la contemplación de obras de arte o la audición reposada de la música permiten detener el pensamiento de su vorágine promovida por las obligaciones diarias abriendo el espacio y el tiempo necesarios para la reflexión. Pero esto que parece propio del buen uso del tiempo libre no es suficiente en el acto académico. Las humanidades son más que ello y sin ánimo de reducirlas a compartimientos estancos debemos mencionar a la filosofía, la historia, la ética, la lingüística y las ciencias sociales, disciplinas que los estudiantes universitarios deberían estar familiarizados no tanto como cursos donde se tiene un único libro de texto y que son evaluados mediante pruebas de respuesta múltiple sino como cursos donde los alumnos, a la par que adquieren conceptos, desarrollen una capacidad de lectura crítica, de formar argumentos sustentados, de ser creativos e imaginativos así como tener la capacidad de comunicar sus ideas de un modo coherente.

La formación de un pensamiento crítico es el mejor antídoto contra los fundamentalismos que pueblan la práctica médica, tan apegada hoy a la tiranía de los algoritmos y a la monotonía ciega de las guías clínicas. En un escenario donde los conocimientos se han fragmentado hasta la ultra subespecialización, las habilidades para integrar conocimientos de diversas disciplinas y el ejercicio de la profesión en función de la persona particular se convierten en un privilegio y en una ventaja comparativa, esto último expresado en un lenguaje tan preciado a las prácticas de administración. 
Una ventaja adicional, no menos importante y acaso la medular, es la formación de personas con ética, en una época en que parece haberse dejado de lado. Ante la barbarie de la modernidad, donde algunas actividades humanas y profesionales tienen un precio, la verdad a veces es solo una apariencia y el éxito individual medido en bienes intenta imponerse sobre el colectivo o a costa del planeta. La formación de personas con valores, de ciudadanos conscientes de su pertenencia a una sociedad justa e inclusiva hará que las inequidades y abusos de cualquier tipo sean cada vez menores.

Hoy más que nunca necesitamos personas antes que humanos robotizados, que la filosofía nos enseñe a pensar, que la historia y las ciencias sociales nos pongan en contexto, que la literatura nos muestre los distintos pliegues de la condición humana y nos haga entendibles las enormes capacidades del lenguaje y la palabra. Ahora, que la tecnología esta a punto de devorar a sus creadores para hacerlos útiles a ella, cuando una generación de jóvenes cree, más que antes, que la historia comienza con ellos, ignorando los sacrificios que ha costado a la humanidad alcanzar este relativo progreso.
Los fundadores de esta casa de estudios, consecuentes a sus propios valores, dieron un salto al vacío para crear una universidad acorde a sus ideales sobre el ejercicio correcto de la medicina, con valores humanos y curiosidad por la ciencia. De este modo, la comunidad herediana se forjó con el concurso mancomunado de profesores y alumnos. Aquel salto no fue al vacío, se hizo lo correcto, no solo empujando el avance de la ciencia sino desarrollando actividades culturales y de filosofía que hoy se ven un tanto lejanas. Donde las aulas universitarias y las asociaciones estudiantiles eran espacios de discusión no solo de ciencia sino de la realidad nacional.

El nuevo siglo encuentra no solo un país distinto sino una sociedad y una corriente de pensamiento que ha sabido sortear las crisis de la república. Mientras vamos acordes al desarrollo científico y administrativo estamos en el momento de tomar un nuevo impulso en la adopción de las humanidades como medio para formar personas, buenos ciudadanos y mejores profesionales donde la capacidad crítica y la empatía con el otro sean competencias profesionales incorporadas, donde las humanidades sean vistas como complementarias y no suceda como hace poco cuando conversando con un estudiante de medicina sobre las humanidades me respondió: Y, ¿Para qué sirven?

\section{Aldo Vivar Mendoza}

Profesor auxiliar, Facultad de Medicina, UPCH 